\title{
International and National Security Includes a Sustainable Biosphere
}

\author{
Jack T. Trevors
}

Received: 1 February 2010 /Accepted: 2 February 2010 / Published online: 23 February 2010

(C) Springer Science+Business Media B.V. 2010

Most activities that sovereign countries engage in can be considered a form of national security. These activities include agriculture, food safety and security, research, innovation, public health, education, healthcare, transportation, energy grids, communication, civil law, justice systems, military, non-corrupt financial systems, basic human rights and needs, democratic elections, honest visionary leadership and lack of conflicts, as examples. The more democratic countries present in the world, the easier it is for global international security to prevail. National and international security is extremely challenging in the face of global pollution, an overpopulated planet, conflicts, wars, discrimination, super capitalism and consumption, excess waste, dictatorships, failed states, organized crime, thugs and criminals, and in countries lacking basic infrastructure and violating human rights. Good national security equates to good international security. Democratic countries with evolving national security can share their science, technology, and knowledge, provide foreign aid, assist other countries in a time of crisis, engage in regulated and free trade, and have a better opportunity to conduct their activities in a peaceful manner, including international pollution accords with agreements that are legally binding.

J. T. Trevors $(\bowtie)$

School of Environmental Sciences, University of Guelph,

Guelph, Ontario, Canada N1G 2W1

e-mail: jtrevors@uoguelph.ca
Of the current about 195 countries in the world, there are many that are still not democratic, are unstable states, or are completely failed states. These countries often do not have the capability to evolve a democracy and/or the dictators running them do not desire a form of democratic national security. This makes it difficult for other countries to engage in meaningful agreements to help the often oppressed citizens of those countries. The lack of national security in these countries also makes it difficult to implement much needed birth control programs and pollution control programs, both needed in our singular, common biosphere. It is the role of every democratic country to assist non-democratic countries in every way possible to evolve into democracies where the rights of the individual are placed ahead of the rights of the state.

National security also includes both public and private education where scholarship, debates, innovation, and research are part of the driving force behind greener, sustainable countries and ensuring a sustainable biosphere for humanity. All citizens in all countries need to be partners in humanity. The younger generation in both democratic and nondemocratic countries should choose their idols carefully; if they want a better world, choose (and become knowledgeable about) those individuals and organizations who have devoted their lives to humanity. Think of the great visionary leaders, thinkers and philosophers, and scientists such as Nelson Mandela, Martin Luther King, Abraham Lincoln, Doctors without Borders, Mother Teresa, Mahatma Ghandi, Desmond 
Tutu, Albert Schweitzer, Lao Zi, Confucius, Socrates, Plato, Karl Marx, Michelangelo, Euclid, Archimedes, Leonardo da Vinci, Galileo, Isaac Newton, James Watt, Michael Faraday, Louis Pasteur, Albert Einstein, James Watson and Francis Crick, Alexander Graham Bell and Guglielmo Marconi, to name a few examples.

The educational system in every country has an immense role in educating the global citizens of today and tomorrow. Education systems must help in every manner possible to evolve our modern democracies by educating the leaders of tomorrow. One could even argue that the role of the modern university is to evolve modern global democracies. If we get democracy right, our other challenges/ problems are much easier to solve, including global pollution. 